\title{
The Purification of Glycerate Kinase from Hyphomicrobium sp. and Pseudomonas AM1 : Product Identification
}

\author{
By B. HILL AND MARGARET M. ATTWOOD \\ Department of Microbiology, University of Sheffield, Sheffield SI 2 TN
}

(Received I 2 February 1974; revised 4 March 1974)

\section{INTRODUCTION}

Aerobic bacteria grown on methanol can utilize one of two pathways for carbon assimilation, either the serine pathway or the pentose phosphate cycle of formaldehyde fixation. Both Pseudomonas Am I (Heptinstall \& Quayle, 1970; Harder \& Quayle, I97I) and Hyphomicrobium $\mathrm{X}$ and $\mathrm{G}$ (Harder \& Attwood, 1973) utilize the serine pathway. During work on the carbon assimilation pathway of methanol-grown Hyphomicrobium sp. the relative rates of conversion of glycerate, 2-phosphoglycerate and 3-phosphoglycerate into phosphoenolpyruvate indicated that 2-phosphoglycerate was the product of the glycerate kinase. The conversion of 2-phosphoglycerate into 3-phosphoglycerate may be the first step in the biosynthesis of cellular material (Harder, Attwood \& Quayle, 1973). Glycerate kinase has been purified from both methanol-grown Hyphomicrobium $\mathrm{x}$ and Pseudomonas AM $\mathrm{I}$ and the product of the reaction identified.

\section{METHODS}

Organisms. The maintenance of Hyphomicrobium $\mathrm{x}$ and growth in liquid inorganic salts medium with methanol $(0.5 \%, \mathrm{v} / \mathrm{v})$ was as described by Harder et al. (1973). Pseudomonas AM I (NCIB9I 33) was maintained and grown in liquid culture as described by Salem, Hacking \& Quayle (1973) using methanol $(0.5 \%, \mathrm{v} / \mathrm{v})$ as carbon source.

Preparation of cell-free extracts. Bacteria were disrupted using an ultrasonic disintegrator (Harder et al. 1973). The supernatant fluids after centrifugation at $15000 \mathrm{~g}$ for $\mathrm{I} 5 \mathrm{~min}$ at $0{ }^{\circ} \mathrm{C}$ were used as the crude extracts.

Enzyme assays. Glycerate kinase (EC. 2.7.I.31) was assayed by the method described by Heptinstall \& Quayle (1970). Phosphoglycerate mutase (EC. 2.7.5.3) was assayed by a modification of the method described in the Biochemica catalogue (I 968), C. F. Boehringer und Soehn GmbH, Mannheim, Germany (Harder et al. 1973).

Protein determination. Protein was assayed by the Folin Ciocalteu method as described by Lowry, Rosebrough, Farr \& Randall ( I95I). Bovine serum albumin (Armour Pharmaceutical Co., Eastbourne, Sussex) was used as the standard.

Purification. All buffers used during the purification contained mercaptoethanol (2 $\mathrm{mm}$ ) and magnesium chloride ( $5 \mathrm{~mm}$ ). The crude enzyme extract was brought to $30 \%$ saturation with ammonium sulphate and allowed to stand at $0{ }^{\circ} \mathrm{C}$ for $30 \mathrm{~min}$. The precipitate was collected by centrifugation at $15000 \mathrm{~g}$ for $10 \mathrm{~min}$ and then discarded. The supernatant was then brought to $50 \%$ saturation by a further addition of ammonium sulphate and allowed to stand as before. The precipitate was collected by centrifugation, resuspended in $50 \mathrm{~mm}-$ sodium phosphate buffer, $\mathrm{pH} 7 \cdot 3$, and applied to a Sephadex G-50 column $(15 \times 1.5 \mathrm{~cm})$ 
Table I. Purification of glycerate kinase from Hyphomicrobium $\mathrm{x}$

and Pseudomonas AM I

Fraction

\begin{tabular}{|c|c|c|c|c|c|}
\hline Fraction & $\begin{array}{c}\text { Total } \\
\text { activity } \\
\text { (//mol/min) }\end{array}$ & $\begin{array}{l}\text { Total } \\
\text { protein } \\
(\mathrm{mg})\end{array}$ & $\begin{array}{c}\text { Specific } \\
\text { activity } \\
\text { ( } / \text { mol/min/ } \\
\text { mg protein) }\end{array}$ & $\begin{array}{l}\text { Yield } \\
(\%)\end{array}$ & Purification \\
\hline \multicolumn{6}{|l|}{ Hyphomicrobium extract } \\
\hline Crude enzyme & $6 \cdot 9$ & $94^{\circ} 0$ & 0.07 & 100 & - \\
\hline $50 \%\left(\mathrm{NH}_{4}\right)_{2} \mathrm{SO}_{4}$ precipitate & $4 \cdot 0$ & 25.5 & 0.16 & $58 \cdot 3$ & $2 \cdot 3 \times$ \\
\hline Sephadex G-5o filtration & $3 \cdot 0$ & $15 \cdot 0$ & 0.20 & $43 \cdot 5$ & $2 \cdot 9 \times$ \\
\hline DEAE-cellulose chromatography & $2 \cdot 2$ & 0.8 & $2 \cdot 73$ & $31 \cdot 9$ & $37 \cdot 4 \times$ \\
\hline \multicolumn{6}{|l|}{ Pseudomonas AMI extract } \\
\hline Crude enzyme & $6 \cdot 2$ & I $52 \cdot 8$ & 0.04 & 100 & $\ldots$ \\
\hline $50 \%\left(\mathrm{NH}_{4}\right)_{2} \mathrm{SO}_{4}$ precipitate & $1 \cdot 5$ & $81 \cdot 9$ & 0.02 & $24 \cdot 2$ & $0.4 \times$ \\
\hline Sephadex G-50 filtration & $I \cdot I$ & $53 \cdot 4$ & 0.02 & $17 \cdot 7$ & $0.4 \times$ \\
\hline $\begin{array}{l}\text { DEAE-cellulose chromatography } \\
\text { (mutase free) }\end{array}$ & $1 \cdot 3$ & $5 \cdot 3$ & $0 \cdot 24$ & $21 \cdot 0$ & $5 \cdot 9 \times$ \\
\hline $\begin{array}{l}\text { DEAE-cellulose chromatography } \\
\text { (contaminated with mutase) }\end{array}$ & 0.3 & $5 \cdot 2$ & 0.05 & $4 \cdot 8$ & $\mathrm{I} \cdot 3 \times$ \\
\hline
\end{tabular}

equilibrated with $10 \mathrm{~mm}$-sodium phosphate buffer, $\mathrm{pH} 7{ }^{\circ} \mathrm{O}$. The column was eluted and fractions $(\mathrm{I} \cdot 7 \mathrm{ml})$ were collected and monitored at $280 \mathrm{~nm}$; the flow rate was $0.82 \mathrm{ml} / \mathrm{min}$. Fractions showing absorbance at $280 \mathrm{~nm}$ were assayed for glycerate kinase activity. All tubes showing activity were bulked ( $10 \mathrm{ml}$ ) and placed at the top of a DEAE-cellulose DE-52 column ( $5 \times 1 \cdot 5 \mathrm{~cm})$ equilibrated with $10 \mathrm{~mm}$-sodium phosphate buffer, $\mathrm{pH} 7 \cdot 0$. The column was eluted using the same buffer containing a continuous linear gradient of sodium chloride ( $\mathrm{O}$ to I M). Fractions $(4 \mathrm{ml}$ ) were collected and monitored as before for absorbance at $280 \mathrm{~nm}$. The flow rate was $0.4 \mathrm{ml} / \mathrm{min}$. Tubes were assayed for glycerate kinase activity. Those showing activity were then assayed for phosphoglycerate mutase activity.

Product identification. The purified glycerate kinase free from phosphoglycerate mutase activity $(\mathrm{I} \cdot 3 \mathrm{ml})$ was incubated in the following mixture at $30^{\circ} \mathrm{C}$ for $15 \mathrm{~min}$ : sodium phosphate buffer $\mathrm{pH} 7 \cdot 3$, $100 \mu \mathrm{mol}$; ATP, $5 \mu \mathrm{mol}$; glycerate, $4 \mu \mathrm{mol}$; EDTA, $3 \mu \mathrm{mol}$; and magnesium chloride, $30 \mu \mathrm{mol}$, in a total volume of $3.8 \mathrm{ml}$. The reaction was terminated by placing the tube in ice at $0{ }^{\circ} \mathrm{C}$. Samples of the incubation mixture were taken for product identification by the enzymic method of Czok \& Eckbert (1965). 2-Phosphoglycerate is converted to L-lactate by the addition of commercially purified enzymes. The NADH used in the production of lactate from pyruvate is followed spectrophotometrically at $340 \mathrm{~nm}$.

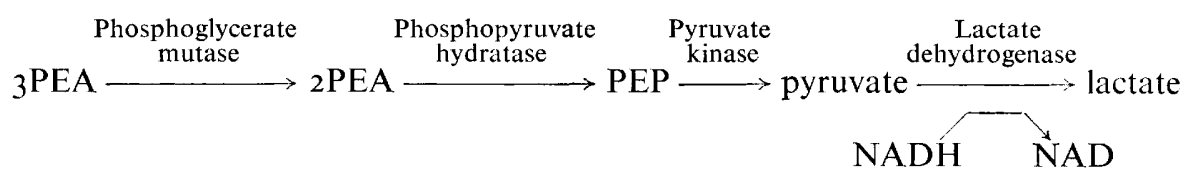

The reaction mixture for product identification contains tris buffer $\mathrm{pH} 7 \cdot 3,50 \mu \mathrm{mol}$; ADP, $0.5 \mu \mathrm{mol}$; NADH, $0.15 \mu \mathrm{mol} ; 2,3$-diphosphoglyceric acid, $0.0 \mathrm{r} \mu \mathrm{mol}$; sample and water to $\mathrm{I} \cdot 0 \mathrm{ml}$. The extinction at $340 \mathrm{~nm}$ was recorded and then the linkage enzymes were added separately and in excess in the following order: lactic dehydrogenase, pyruvate kinase, phosphopyruvate hydratase and phosphoglycerate mutase. After each addition the total change in extinction at $340 \mathrm{~nm}$ was recorded. 

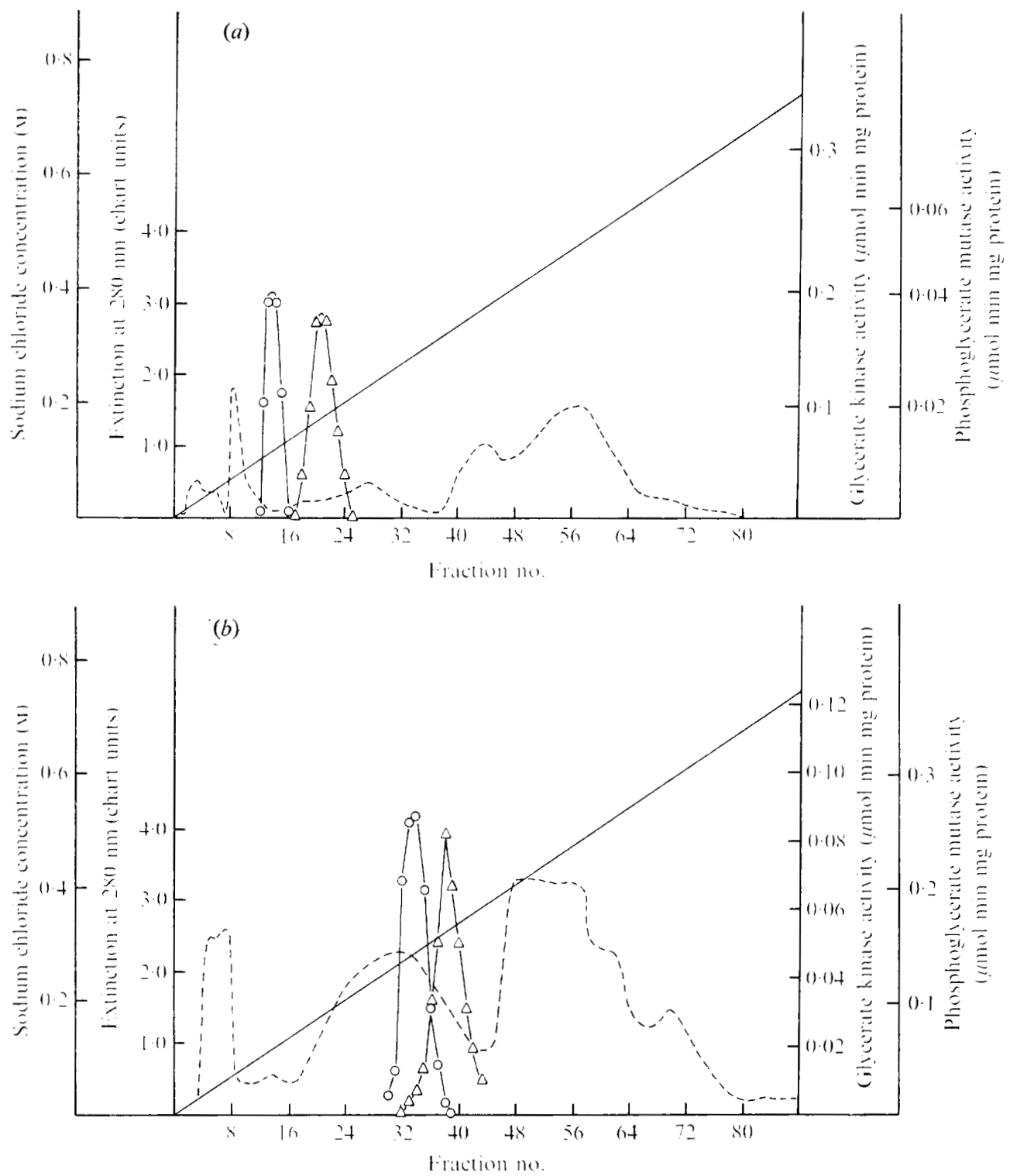

Fig. I. $280 \mathrm{~nm}$ absorption pattern of fractions eluted from DEAE cellulose columns. (a) Extract from methanol-grown Hyphomicrobium x. (b) Extract from methanol-grown Pseudomonas Am I. 0 , Kinase activity; $\triangle$, phosphoglycerate mutase activity; broken line, extinction at $280 \mathrm{~nm}$; solid line, sodium chloride gradient.

\section{RESULTS AND DISCUSSION}

The purification of the enzyme was followed by measuring the glycerate kinase activity at each purification step. A summary of the purification scheme is shown in Table I. Only one peak of glycerate kinase activity was detected from the DEAE cellulose columns (Fig. I $a, b$ ). All the tubes showing glycerate kinase were then assayed for phosphoglycerate mutase activity. The whole of the Hyphomicrobium glycerate kinase peak was free from 
phosphoglycerate mutase activity. When Pseudomonas Am I extracts were used the initial fractions of phosphoglycerate mutase activity were eluted together with the later fractions of glycerate kinase activity (Fig. I $b$ ). In this case only the early fractions of glycerate kinase free from phosphoglycerate mutase were used for product identification.

The product of the glycerate kinase from both organisms was identified as 2-phosphoglycerate. No decrease in extinction at $340 \mathrm{~nm}$ was observed upon the addition of lactic dehydrogenase or pyruvate kinase. Thus pyruvate and phosphoenolpyruvate were not present in the product identification mixture. On the addition of phosphopyruvate hydratase a rapid decrease in extinction at $340 \mathrm{~nm}$ was observed, indicating the presence of 2-phosphoglycerate. No further reduction in optical density occurred upon the addition of commerically purified phosphoglycerate mutase. This was not due to the exhaustion of $\mathrm{NADH}$ or any other component of the product identification mixture, since the addition of 3-phosphoglycerate rapidly reduced the extinction further. Thus no 3-phosphoglycerate was originally present in the product identification mixture and the product of the glycerate kinase reaction was 2-phosphoglycerate. From the total change in extinction on the addition of each separate linkage enzyme the actual amount of product in the sample can be calculated. The total amount of 2-phosphoglycerate formed $(0.49 \mu \mathrm{mol} / \mathrm{ml}$ using Hyphomicrobium glycerate kinase and $0.23 \mu \mathrm{mol} / \mathrm{ml}$ using Pseudomonas AM I glycerate kinase) during the incubation period was seen to be consistent with the amount of product expected $(0.66$ $\mu \mathrm{mol} / \mathrm{ml}$ for Hyphomicrobium glycerate kinase and $0.36 \mu \mathrm{mol} / \mathrm{ml}$ for Pseudomonas Am I glycerate kinase) from the purified glycerate kinase activity added in that mixture and incubated for $15 \mathrm{~min}$ at $30^{\circ} \mathrm{C}$. The identification of 2-phosphoglycerate as the product of glycerate kinase agrees with that of the glycerate kinase in rat liver (Lamprecht, Heinz \& Diamartstein, 1962) and in methanol-grown Pseudomonas MS (E. Bellion, personal communication) but differs from the glycerate kinase of glycerate adapted E. coli (Doughty, Hayashi \& Guenther, 1966) where 3-phosphoglycerate was the identified product.

B.H. wishes to acknowledge the receipt of an S.R.C. research studentship.

\section{REFERENCES}

Czok, R. \& Eckвert, L. (1965). D-3 Phosphoglycerate, D-2 phosphoglycerate, phosphoenolpyruvate. In Methods of Enzymatic Analysis, 2nd edn, p. 229. Edited by H.-U. Bergmeyer. New York, London: Academic Press.

Doughty, C. C., Hayashi, J. A., Guenther, H. L. (1966). Purification and properties of D-glycerate 3 kinase from Escherichia coli. Journal of Biological Chemistry 24I, 568-572.

Harder, W. \& Atrwood, M. M. (1973). The metabolism of organic compounds in Hyphomicrobium: pathway of carbon assimilation during growth on methanol. Antonie van Leeuwenhoek 39, 358.

Harder, W. \& Quayle, J. R. (1971). Aspects of glycine and serine biosynthesis during growth of Pseudomonas AMI on $\mathrm{C}_{1}$ compounds. Biochemical Journal r2r, 763-769.

Harder, W., Attwood, M. M. \& Quayle, J. R. (1973). Methanol assimilation by Hyphomicrobium sp. Journal of General Microbiology 78, I 55-163.

Heptinstall, J. \& Quayle, J. R. ( I970). Pathways leading to and from serine during growth of Pselidomonas AMI on $\mathrm{C}_{1}$ compounds or succinate. Biochemical Journal 117, 563-572.

Lamprecht, W., Heinz, F. \& Diamartstein, T. (i962). Phosphorylierung von D-Glycerinsäure zu 2-PhosphoD-Glycerinsäure mit Glyceratkinase in Leber. Identifizierung des Reaktionsproduktes durch Papierchromatographie. Zeitschrift für Physiologische Chemie 328, 204-206.

Lowry, O. H., Rosebrough, N. J., Farr, A. L. \& Randall, R. J. (I95I). Protein measurement with the Folin phenol reagent. Journal of Biological Chemistry I93, 265-275.

Salem, A. R., Hacking, A. J. \& Quayle, J. R. (1973). Cleavage of malyl coenzyme A into acetyl coenzyme A and glyoxylate by Pseudomonas AMI and other $\mathrm{C}_{1}$ unit utilizing bacteria. Biochemical Journal $\mathbf{1 3}^{6}$, 8996. 